(c) American Dairy Science Association, 2006.

\title{
Short Communication: Genetic Selection for Milk Production Increases Plasma Ghrelin in Dairy Cows
}

\author{
J. R. Roche, ${ }^{, 1,2}$ A. J Sheahan, ${ }^{*}$ L. M. Chagas, ${ }^{\star}$ and D. P. Berry† \\ *Dexcel, Hamilton, New Zealand \\ †Teagasc Moorepark, Fermoy, County Cork, Ireland
}

\begin{abstract}
Ghrelin is an endogenous ligand of the growth hormone secretagogue receptor and a potent orexigenic agent in human and rodent studies, but there is limited information about its effect in dairy cows. Twelve low genetic merit and 9 high genetic merit HolsteinFriesian dairy cows in peak lactation that were offered unrestricted access to fresh pasture were used to determine whether genetic selection for milk production resulted in an associated increase in plasma ghrelin concentration in grazing dairy cows. Blood samples were taken prior to the a.m. milking (i.e., baseline) and following $2 \mathrm{~h}$ of grazing after the a.m. milking on 2 consecutive wk during peak lactation. Milk production and dry matter intake were greater in high genetic merit cows compared with low genetic merit cows. Plasma ghrelin and growth hormone concentrations were elevated in high genetic merit cows pre- and postgrazing, and there was no significant interaction between genetic merit and time of sampling. Genetic merit did not affect the plasma nonesterified fatty acid or glucose concentration, but the plasma concentrations of metabolites and hormones measured were diminished $2 \mathrm{~h}$ after feeding. Data indicate an increase in plasma ghrelin associated with genetic selection for milk production, and an associated increase in dry matter intake.
\end{abstract}

Key words: genetic merit, ghrelin, dry matter intake, milk production

The initiation of lactation dramatically alters the metabolism of many organs so that the mammary gland can be supplied with the nutrients necessary for milk synthesis (Bauman and Currie, 1980). Few factors could be regarded as more important in this

Received March 19, 2006.

Accepted April 3, 2006.

${ }^{1}$ Corresponding author: john.roche@utas.edu.au

${ }^{2}$ Current address: University of Tasmania, PO Box 3523, Burnie, Tasmania 7320, Australia. homeorhetic process than the hyperphagia associated with early lactation.

Consistent with this, genetic selection for milk production has resulted in increased DMI (Kennedy et al., 2003; Linnane et al., 2004; Kolver et al., 2005), probably as a result of either associated genes being closely linked or pleiotropic gene effects (i.e., genes that affect milk production also affect DMI; Veerkamp et al., 2003). However, this pleiotropy may also extend to increased body tissue mobilization in early lactation and a reduced propensity to partition nutrients toward body tissue replenishment during lactation (Roche et al., 2006). Greater negative energy balance (NEBAL) is undesirable because of associated negative effects on reproductive performance in dairy cows (Beam and Butler, 1999; Buckley et al., 2003) and a consequential reduction in the profitability of grazing systems (Veerkamp et al., 2002). The conundrum that therefore exists is how to continue selection for increases in DMI without exacerbating the already problematic NEBAL.

One possibility may be in genetic selection for markers of ghrelin production, if such a trait is related to increased DMI in dairy cows. Ghrelin is one of the most powerful peripherally active orexigenic agents known (Wren et al., 2001). Although initially identified as a growth hormone secretagogue (Kojima et al., 1999), ghrelin has since been reported to have nongrowth hormone-related effects (Korbonits and Grossman, 2004), stimulating DMI, body growth and adiposity, and milk production in rodent models (Tschop et al., 2000; Nakahara et al., 2003). It has also been associated with the regulation of other endocrine functions, such as prolactin, cortisol, and luteinizing hormone (Korbonits and Grossman, 2004). However, there is limited information about this hormone in lactating dairy cows (Robinson et al., 2006). The objective of this study was to determine whether genetic selection for increased milk production was associated with increased plasma concentrations of ghrelin.

Twenty-one low genetic merit $(\mathbf{L G M} ; \mathrm{n}=12)$ and high genetic merit (HGM; $\mathrm{n}=9$ ) Holstein-Friesian cows in peak lactation were offered unrestricted access to fresh pasture. Blood samples were taken prior to 
Table 1. Mean (and SD) botanical (\%DM) and nutrient (\%DM) composition, OM digestibility $(\% \mathrm{DM})$, and $\mathrm{ME}$ content $(\mathrm{MJ} / \mathrm{kg}$ of $\mathrm{DM})$ of pasture offered

\begin{tabular}{lcc}
\hline Variable & Mean & SD \\
\hline Ryegrass leaf & 72.9 & 8.44 \\
Ryegrass stem & 11.1 & 2.23 \\
Clover & 14.0 & 5.58 \\
Weeds & 0.2 & 0.22 \\
Dead & 1.8 & 0.44 \\
CP & 20.3 & 3.74 \\
NDF & 46.7 & 5.34 \\
ADF & 22.7 & 1.07 \\
Lipid & 4.3 & 0.06 \\
Nonstructural carbohydrates & 17.4 & 4.53 \\
OM digestibility & 82.6 & 1.80 \\
ME & 12.2 & 0.30 \\
Ash & 9.9 & 1.27 \\
\hline
\end{tabular}

the a.m. milking (i.e., baseline) and following $2 \mathrm{~h}$ of grazing after the a.m. milking on 2 consecutive wk during peak lactation.

The 2 strains were selected to be divergent in EBV for milk production, but were balanced for age and $\operatorname{DIM}(5.5 \pm 0.67$ and $4.7 \pm 1.32 \mathrm{yr}$, and $82 \pm 16.0$ and $65 \pm 17.2 \mathrm{DIM}$, for LGM and HGM, respectively). The mean EBV were obtained from the Livestock Improvement Corporation, New Zealand, evaluations (December 2005). The mean EBV for the LGM animals under study were +412 (SD 242.1) $\mathrm{kg}$ of milk, +13 (SD 7.3) $\mathrm{kg}$ of fat, +7 (SD 4.7) $\mathrm{kg}$ of protein, and +41 (SD 15.6) $\mathrm{kg}$ of BW, whereas the EBV for the HGM cows were +806 (SD 224.7) kg of milk, +32 (SD 7.3) kg of fat, +31 (SD 4.7) $\mathrm{kg}$ of protein, and +55 (SD 15.6) $\mathrm{kg}$ of BW.

Grazing management was similar to that described by Roche et al. (2006). Briefly, cows were rotationally grazed as one herd and were assigned a grazing area only when a minimum of 2 leaves had appeared on the majority $(>75 \%)$ of perennial ryegrass tillers. Cows had access to a new allocation of pasture daily. Pasture allowance ( $>40 \mathrm{~kg}$ of DM/cow per d) was sufficient to ensure unrestricted DMI (up to approximately $25 \mathrm{~kg}$ of $\mathrm{DM} / \mathrm{d}$ ) of fresh pasture. Despite the high grazing residuals, quality was maintained (Table 1) through strategic use of mowing following grazing.

Representative samples of pasture were collected daily by plucking pasture to grazing height from paddocks due to be grazed. Samples were bulked weekly, and duplicate samples were dried at $60^{\circ} \mathrm{C}$ for $48 \mathrm{~h}$, ground to pass through a $1.0-\mathrm{mm}$ sieve (Christy Lab Mill, Suffolk, UK), and analyzed for CP, NDF, ADF, nonstructural carbohydrates, fat, $\mathrm{ME}$, ash, and $\mathrm{OM}$ digestibility by near infrared spectroscopy (Corson et al., 1999).

Individual milk yields were recorded daily (Westfalia Surge, Oelde, Germany). Fat, CP, and lactose concentrations of milk were determined by Milkoscan (Foss Electric, Hillerød, Denmark) on individual p.m. and a.m. aliquot samples, with the a.m. samples coinciding with the same day as blood sampling. Milk component data were verified by reference techniques for a subset of milk samples (milk fat, Röese-Gottlieb technique; $\mathrm{CP}$, Kjeldahl technique). Body weight was determined weekly following the a.m. milking.

Mean DMI was calculated from milk energy output and cow maintenance requirements, accounting positively or negatively for BW gain or loss, respectively, as described by Roche et al. (2005). Energy intake was divided by the mean pasture ME concentration to calculate DMI:

\section{DMI $(\mathrm{kg}$ of $\mathrm{DM} / \mathrm{d})=$}

$\frac{\text { milk energy }+ \text { maintenance energy }+ \text { true BW gain }}{\text { pasture } \mathrm{ME}}$

Two evacuated blood tubes, (140 IU sodium heparin and $0.117 \mathrm{~mL}$ of $15 \% \mathrm{~K}_{3} \mathrm{EDTA}$ ) were collected from each cow by coccygeal venipuncture prior to the a.m. milking and $2 \mathrm{~h}$ following the return to pasture, and plasma was extracted $\left(1,120 \times g, 10 \mathrm{~min}, 4^{\circ} \mathrm{C}\right)$. Plasma samples from the EDTA-blood tubes were acidified using $0.1 \mathrm{~N} \mathrm{HCl}$ and treated with phenylmethylsulfonyl fluoride $\left(\mathrm{C}_{7} \mathrm{H}_{7} \mathrm{FO}_{2} \mathrm{~S}\right)$, following kit instructions (Ghrelin Active Kit; Linco, St. Charles, MO, cat. no. GHRA-88HK), prior to storage and analysis for plasma ghrelin concentration.

Analyses for NEFA (colorimetric method) and glucose (hexakinase method) were performed on a Hitachi 717 analyzer (Roche, Basel, Switzerland) at $30^{\circ} \mathrm{C}$ by Alpha Scientific Ltd. (Hamilton, New Zealand). The inter- and intra-assay coefficient of variation was $<2 \%$ for NEFA and glucose. Growth hormone and ghrelin were measured in duplicate by double-antibody radioimmunoassay with an inter- and intra-assay coefficient of variation $<10 \%$.

A total of 42 prefeeding and 42 postfeeding records of plasma metabolite and hormone concentrations were available for analysis. Preliminary analysis of all data revealed a positively skewed distribution for plasma ghrelin, growth hormone, and NEFA concentration. The natural logarithm of all 3 variables was used to normalize the distribution; the Shapiro-Wilk test signified a normal distribution following transformation.

Mixed-model methodology using the PROC MIXED procedure (SAS Institute, 2006) was used to investigate the effects of genetic merit, parity, and time of measurement (i.e., pre- or postfeeding) on plasma ghrelin, growth hormone, NEFA, and glucose concentrations using all data. Cow was included as a random 
effect. A full model was initially created with all main effects and interactions included as classification variables, and DIM at sampling was included as a continuous variable. Terms were sequentially removed from the model using backward elimination of nonsignificant $(P>0.05)$ effects based on the $F$-test. Least squares means were extracted from the analysis. The main effects of genetic merit, time of sampling, and parity were always forced into the model to facilitate the estimation of the respective least squares means. Mixed-model analyses were also undertaken to determine the effect of genetic merit, after adjusting for parity and DIM, on milk production and DMI.

As predicted from the EBV for milk production, HGM cows produced more $(P<0.05)$ milk than LGM cows (26.9 vs. $22.8 \mathrm{~kg}$, respectively). Mean fat, protein, and lactose contents were not affected by genetic merit ( 4.29 vs. $4.63 \%, 3.23$ vs. $3.38 \%$, and 4.95 vs. $4.89 \%$ of fat, protein, and lactose for HGM and LGM, respectively), but component yield was greater $(P<0.05)$ in HGM cows. Change in BW over the measurement period did not differ significantly between genetic merit groups ( 0.78 vs. $0.88 \mathrm{~kg} / \mathrm{d}$ for HGM and LGM, respectively), suggesting that the difference in milk production at peak lactation in the current study was primarily a result of the difference in pasture DMI ( $P$ $<0.05 ; 17.1$ vs. $15.8 \mathrm{~kg}$ of DM/cow per d for HGM and LGM, respectively). Kennedy et al. (2003) and Linnane et al. (2004) also reported higher DMI in HGM cows, and greater responses to supplements in HGM cows have been associated with less substitution of supplements for pasture (Kennedy et al., 2002; Kolver et al., 2005), presumably because of a greater drive to produce milk and hence eat.

Plasma ghrelin and growth hormone concentrations were greater $(P<0.05)$ in HGM cows pre- and postgrazing, and no significant interaction between cow genetic merit and time of sampling was evident (Table 2). Genetic merit did not affect the plasma NEFA or glucose concentration. Plasma concentrations of all metabolites and hormones measured were diminished $(P<$ 0.001) $2 \mathrm{~h}$ after feeding. Days in milk did not significantly affect plasma ghrelin and growth hormone concentrations, although it did significantly affect NEFA and glucose concentrations. However, the range in DIM (mean $=81 \mathrm{~d}$; SD $=19 \mathrm{~d}$ ) was narrow in the present study.

The greater plasma concentration of growth hormone in HGM cows is consistent with previous studies (Hart et al., 1978) and with the increased milk production associated with exogenous administration of bST (Bauman, 1999). However, the effect of genetic selection for milk production in dairy cows on plasma ghrelin concentration was not previously known.
Ghrelin is a natural ligand of the growth hormone secretagogue and a potent orexigenic agent (Kojima and Kangawa, 2005). Exogenous administration of ghrelin in both rodent (Nakazato et al., 2001; Nakahara et al., 2003) and human (Wren et al., 2001; Neary et al., 2004) studies increased growth hormone production, DMI, lipogenesis, and milk production, but there is a paucity of information on its effect in dairy cows. Plasma ghrelin has been shown to increase in anticipation of a meal and decline postprandially in sheep (Sugino et al., 2004).

Itoh et al. (2005) reported declining ghrelin concentrations as cows went from early to mid and late lactation, suggesting greater ghrelin production in cows in greater NEBAL. In the present study, DIM did not significantly affect plasma ghrelin concentration, although only a limited range in DIM (i.e., 47 to 109 DIM) was represented. However, ghrelin has been positively associated with hunger score in humans (Cummings et al., 2004), indicating a greater appetite drive with increasing plasma ghrelin concentrations. The positive effect of ghrelin on DMI and milk production in rodent models is consistent with the greater DMI and milk production in HGM compared with LGM cows in the current study, and the associated trends in plasma ghrelin concentration. These findings suggest a greater appetite in HGM than LGM cows, a result consistent with those of Kennedy et al. (2003), Linnane et al. (2004) and Kolver et al. (2005). Linnane et al. (2004) reported no effect of genetic strain on either mean total grazing time or the number of daily grazing events, but reported a $6 \%$ increase in the biting rate (bites/min) in HGM compared with LGM cows in their study. These data indicate a more voracious appetite in HGM cows, consistent with the preprandial plasma ghrelin concentrations reported here (301 vs. $241 \mathrm{pg} /$ $\mathrm{mL}$ in HGM and LGM cows, respectively), and the increased appetite score associated with elevated ghrelin concentrations in humans (Cummings et al., 2004).

The higher postprandial plasma ghrelin concentration in HGM cows (173 vs. $127 \mathrm{pg} / \mathrm{mL}$ in HGM and LGM cows, respectively) is also consistent with the reduced negative impact of supplementary feeds in HGM cows compared with lower-merit comparisons (Kennedy et al., 2002; Kolver et al., 2005), with greater ghrelin concentrations postprandially being indicative of a stronger residual appetite. The results presented by Linnane et al. (2004) concur, with LGM cows having a reduced biting rate when supplemented with concentrates but with no effect of concentrate supplementation on biting rate in cows of HGM for milk production.

Results suggest an increase in plasma ghrelin associated with genetic selection for milk production, and 
Table 2. Least squares means and significance of genetic merit for milk production ${ }^{1}$ and timing of sampling (pre- and postprandial) on the plasma concentrations of ghrelin $\left(\log _{\mathrm{e}} \mathrm{pg} / \mathrm{mL}\right)$, growth hormone $\left(\log _{\mathrm{e}} \mathrm{ng} / \mathrm{mL}\right)$, NEFA $\left(\log _{\mathrm{e}} \mathrm{mmol} / \mathrm{L}\right)$, and glucose $(\mathrm{mmol} / \mathrm{L})^{2}$

\begin{tabular}{llccc}
\hline Item & Ghrelin & Growth hormone & NEFA & Glucose \\
\hline Genetic merit & & & & \\
LGM & $5.16(175)$ & $-0.512(0.60)$ & $-2.39(0.09)$ & 3.09 \\
HGM & $5.43(228)$ & $0.115(1.12)$ & $-2.25(0.11)$ & 3.07 \\
SED & 0.100 & 0.3015 & 0.272 & 0.086 \\
$P$-value & $<0.01$ & $<0.05$ & 0.63 & 0.78 \\
Timing & & & $-2.14(0.12)$ & 3.50 \\
Prefeeding & $5.60(270)$ & $0.146(1.16)$ & $-2.50(0.08)$ & 2.66 \\
Postfeeding & $4.99(147)$ & $-0.543(0.58)$ & 0.195 & 0.074 \\
SED & 0.086 & 0.2391 & $<0.001$ & $<0.001$ \\
$P$-value & $<0.001$ & $<0.001$ &
\end{tabular}

${ }^{1} \mathrm{LGM}=$ low genetic merit; HGM = high genetic merit.

${ }^{2}$ Back-transformed least squares means are presented in parentheses for ghrelin (pg/mL), growth hormone (ng/mL), and NEFA (mmol/L).

${ }^{3}$ Standard error of the difference.

an associated increase in DMI. Future research should attempt to quantify the usefulness of plasma ghrelin concentration as a genetic predictor of DMI.

\section{ACKNOWLEDGMENTS}

The authors acknowledge the technical assistance of J. Lee and P. Aspin, all the help afforded them by Dexcel's Lye dairy farm staff, and the laboratory expertise of Alpha Scientific (Hamilton, New Zealand). This work was funded by New Zealand Dairy Farmers through the Dairy InSight research fund.

\section{REFERENCES}

Bauman, D. E. 1999. Bovine somatotropin and lactation: From basic science to commercial application. Domest. Anim. Endocrinol. $17: 101-116$

Bauman, D. E., and B. Currie. 1980. Partitioning of nutrients during pregnancy and lactation: A review of mechanisms involving homeostasis and homeorhesis. J. Dairy Sci. 63:1514-1529.

Beam, S. W., and W. R. Butler. 1999. Effects of energy balance on follicular development and first ovulation in postpartum dairy cows. J. Reprod. Fertil. 54:411-424.

Buckley, F., K. O'Sullivan, J. F. Mee, R. D. Evans, and P. Dillon. 2003. Relationships among milk yield, body condition, cow weight, and reproduction in spring-calving Holstein-Friesians. J. Dairy Sci. 86:2308-2319.

Corson, D. G., G. C. Waghorn, M. J. Ulyatt, and J. Lee. 1999. Forage analysis and livestock feeding. Proc. N. Z. Grassland Assoc. 61:127-132.

Cummings, D. E., R. S. Frayo, C. Marmonier, R. Aubert, and D. Chapelot. 2004. Plasma ghrelin levels and hunger scores in humans initiating meals voluntarily without time- and food-related cues. Am. J. Physiol. Endocrinol. Metab. 287:E297-E304.

Hart, I. C., J. A. Bines, S. V. Morant, and J. L. Ridley. 1978. Endocrine control of energy metabolism in the cow: Comparison of the levels of hormones (prolactin, growth hormone, insulin and thyroxine) and metabolites in the plasma of high- and low-yielding cattle at various stages of lactation. J. Endocrinol. 77:333-345.

Itoh, F., T. Komatsu, M. Yonai, T. Sugino, M. Kojima, K. Kangawa, Y. Hasegawa, Y. Terashima, and K. Hodate. 2005. GH secretory responses to ghrelin and GHRH in growing and lactating dairy cattle. Domest. Anim. Endocrinol. 28:34-45.

Kennedy, J., P. Dillon, L. Delaby, P. Faverdin, G. Stakelum, and M. Rath. 2003. Effect of genetic merit for milk production on grass intake and milk production with Holstein-Friesian dairy cows. J. Dairy Sci. 86:610-621.

Kennedy, J., P. Dillon, P. Faverdin, L. Delaby, F. Buckley, and M. Rath. 2002. The influence of cow genetic merit for milk production on response to level of concentrate supplementation in a grass-based system. Anim. Sci. 75:433-445.

Kojima, M., H. Hosoda, Y. Data, M. Nakazato, H. Matsuo, and K. Kangawa. 1999. Ghrelin is a growth hormone-releasing acylated peptide from stomach. Nature 402:656-658.

Kojima, M., and K. Kangawa. 2005. Ghrelin: Structure and function. Physiol. Rev. 85:495-522.

Kolver, E. S., J. R. Roche, C. R. Burke, and P. W. Aspin. 2005. Influence of dairy cow genotype on milk solids, body condition and reproduction response to concentrate supplementation. Proc. N. Z. Soc. Anim. Prod. 65:46-52.

Korbonits, M., and A. B. Grossman. 2004. Non-growth hormone endocrine actions of ghrelin. Pages 73-89 in Ghrelin. E. Ghigo, ed. Kluwer Academic Publishers, Dordrecht, The Netherlands.

Linnane, M., B. Horan, J. Connolly, P. O'Connor, F. Buckley, and P. Dillon. 2004. The effect of strain of Holstein-Friesian and feeding system on grazing behaviour, herbage intake and productivity in the first lactation. Anim. Sci. 78:169-178.

Nakahara, K., T. Hayashida, M. Nakazato, M. Kojima, H. Hosoda, K. Kangawa, and N. Murakami. 2003. Effect of chronic treatments with ghrelin on milk secretion in lactating rats. Biochem. Biophys. Res. Commun. 303:751-755.

Nakazato, M., N. Murakami, Y. Date, M. Kojima, H. Motsua, K. Kangawa, and S. Matsukura. 2001. A role for ghrelin in the central regulation of feeding. Nature 409:194-198.

Neary, N. M., C. J. Small, A. M. Wren, J. L. Lee, M. R. Druce, C. Palmieri, G. S. Frost, M. A. Ghatei, R. C. Coombes, and S. R. Bloom. 2004. Ghrelin increases energy intake in cancer patients with impaired appetite: Acute, randomized, placebo-controlled trial. J. Clin. Endocrinol. Metab. 89:2832-2836.

Robinson, J. J., C. J. Ashworth, J. A. Rooke, L. M. Mitchell, and T. G. McEvoy. 2006. Nutrition and fertility in ruminant livestock. Anim. Feed Sci. Technol. 126:259-276.

Roche, J. R., D. P. Berry, and E. S. Kolver. 2006. Holstein-Friesian strain and feed effects on milk production, body weight and body condition score profiles in grazing dairy cows. J. Dairy Sci. 89, in press.

Roche, J. R., E. S. Kolver, and J. K. Kay. 2005. Influence of precalving feed allowance on periparturient metabolic and hormonal re- 
sponses and milk production in grazing dairy cows. J. Dairy Sci. 88:677-689

SAS Institute. 2006. User's Guide Version 9.1: Statistics. SAS Institute, Cary, NC.

Sugino, T., Y. Hasegawa, Y. Kurose, M. Kojima, K. Kangawa, and Y. Terashima. 2004. Effects of ghrelin on food intake and neuroendocrine function in sheep. Anim. Reprod. Sci. 82-83:183-194.

Tschop, M. S., D. L. Smiley, and M. L. Heiman. 2000. Ghrelin induces adiposity in rodents. Nature 407:908-913.

Veerkamp, R. F., B. Beerda, and T. van der Lende. 2003. Effects of genetic selection for milk yield on energy balance, levels of hormones, and metabolites in lactating cattle, and possible links to reduced fertility. Livest. Prod. Sci. 83:257-275.

Veerkamp, R. F., P. Dillon, E. Kelly, A. R. Cromie, and A. F. Groen. 2002. Dairy cattle breeding objectives combining yield, survival and calving interval for pasture-based systems in Ireland under different milk quota scenarios. Livest. Prod. Sci. 76:137-151.

Wren, A. M., L. J. Seal, M. A. Cohen, A. E. Brynes, G. S. Frost, K. G. Murphy, W. S. Dhillo, M. A. Ghatei, and S. R. Bloom. 2001. Ghrelin enhances appetite and increases food intake in humans. J. Clin. Endocrinol. Metab. 86:5992-5995. 